\title{
Archipel
}

ARCHIPEL Études interdisciplinaires sur le monde insulindien

$100 \mid 2020$

Varia

\section{In Memoriam Alexander Ogloblin (1939-2020)}

\section{Victor Pogadaev}

\section{OpenEdition}

Journals

Édition électronique

URL : http://journals.openedition.org/archipel/2016

DOI : 10.4000/archipel.2016

ISSN : 2104-3655

\section{Éditeur}

Association Archipel

\section{Édition imprimée}

Date de publication : 15 décembre 2020

Pagination : 5-7

ISBN : 978-2-910513-84-9

ISSN : 0044-8613

\section{Référence électronique}

Victor Pogadaev, «In Memoriam Alexander Ogloblin (1939-2020)», Archipel [En ligne], 100 | 2020, mis en ligne le 28 novembre 2020, consulté le 04 décembre 2020. URL : http://journals.openedition.org/ archipel/2016 ; DOI : https://doi.org/10.4000/archipel.2016 


\section{In Memoriam Alexander Ogloblin (1939-2020)}

A famous scholar of our time, a linguist and expert on Malay-Indonesian world, and more broadly, on Austronesian linguistics, our colleague and friend Alexander Konstantinovich Ogloblin passed away on April 23, 2020 in St. Petersburg.

Alexander Ogloblin was born on January 2, 1939 in Leningrad. He graduated from the Oriental Department of Leningrad State University in 1961 with a diploma qualification on Indonesian philology. His teachers in that field were Indonesian language lecturer, Usman Effendi, the initiator of the first researches of the mathematical method in linguistics, N.D. Andreev, the expert in Indonesian grammar, G. I. Prokofiev.

In 1961-1965 A.K. Ogloblin served in the army as a translator and teacher of Indonesian language while doing doctoral studies by correspondence under the guidance of the professor of theoretical linguistics and orientalist, A.A. Kholodovich.

He got his training in Indonesia (1959-1960, practiced at the USSR Trade Office in Jakarta); in Malaysia (1978-79, University of Malaya in Kuala Lumpur), in Denmark (1995, Nordic Institute of Asian Studies, Copenhagen).

Since 1966, he chaired text-reading seminars at the Oriental Faculty of the St. Petersburg State University (Professor since 1994) and gave lectures on theoretical grammar of Indonesian language and literature, Javanese, Austronesian linguistics, Malay dialectology, and others. In 1988, he defended his doctoral thesis concerning the structure and evolution of Malay-Javanese languages. His publications (books, articles, abstracts and papers, textbooks 
- more than 230 overall) cover languages (especially grammar and typology), literature and culture of the Nusantara world. He is one of the authors of the world's first scientific Grammar of the Indonesian language (1972), which was later reprinted in Indonesia in Indonesian (1991).

For many years he was involved in the researches carried out by the Language Typology Research Laboratory at the Institute of Linguistics of the Russian Academy of Sciences, St. Petersburg. The collective monographs of this laboratory include his works on the categories of causative, passive and reflexive verbs in Indonesian and Javanese languages. In 1986, he published Madurese Grammar, one of the main languages of Indonesia that had never been previously studied in Russia (the work was awarded with the Certificate of Honor by the Russian Ministry of Education), and in 2008 - Grammar of Modern Literary Indonesian Language. He contributed a lot in the compiling of the Kamus Besar Rusia-Indonesia, published in Jakarta (2016).

$\mathrm{He}$ also took part in activities of the Museum of Anthropology and Ethnography of the Russian Academy of Sciences (Kunstkamera, St. Petersburg), and of the Institute of Oriental Studies of the Russian Academy of Sciences (Moscow).

He presented papers at many international conferences and seminars: the 6th Conference on Austronesian linguistics in Honolulu (USA, 1991) and the 7th Conference on Austronesian linguistics at Noordwijkerhout (Netherlands, 1994); Malay Congress in Kuala Lumpur (1995); Conferences on the languages of the Far East, Southeast Asia and West Africa in Moscow (1997), in St. Petersburg (1999), and others; Royal Institute for Anthropology and Linguistics seminars in Leiden on ancient Javanese texts (1998), and on the Malay epistemic tradition (2002); Language Congress in Indonesia in Jakarta (1999), etc.

A.K. Ogloblin published translations of novels and short stories by 20th-century Indonesian writers, namely Pramoedya Ananta Toer (Keluarga Gerilya), Putu Wijaya (Telegram and Bila Malam Bertambah Malam), short stories by S.M. Ardan, Ajip Rosidi, Nugroho Notosusanto, poems by Sitor Situmorang, Toto Sudarto Bachtiar, Subagio Sastriwardojo, Gunawan Mohamad, Wing Kardjo, and many others. In 2016, he published his Russian translation of the book Twaalf eeuwen Javaanse literatuur: een overzicht (2003) by Willem van der Molen.

A.K. Ogloblin was one of the Vice-Presidents of the Nusantara Society (Moscow), the compiler and the author of a series of books on MalayIndonesian culture published by the Nusantara Society together with the Oriental Faculty, St. Petersburg State University. In 1995-1998 he was a Corresponding Member of the Bureau of the European Association for SouthEast Asian Studies (EUROSEAS).

A tireless scholar, teacher and author of many monographs and articles relating to the Malay-Indonesian world, Alexander Konstantinovich Ogloblin 
for most Russian scholars was an example of loyalty to science, a man who was always ready to help his colleagues, to correct the lapses in the works sent to him, to give wise recommendations, being upset, but not offended when they were not always accepted. He, like the character in Javanese mythology, Semar, had an exceptional personality, real Russian-Petersburgian, and in some way a little Javanese - with true Javanese tolerance, complacency with the solid preservation of his ego.

With a number of publications that exceeded 200, he became one of the prominent experts on Austronesian linguistics, but always remained humble and modest. We will always remember him and his big contribution and devotion to the only love of his life: Nusantara.

Victor Pogadaev Associate Professor of Moscow Institute of International Relations, Vice-President of Nusantara Society 
